\title{
Metal-activated C-peptide facilitates glucose clearance and the release of a nitric oxide stimulus via the GLUT1 transporter
}

\author{
J. A. Meyer • J. M. Froelich • G. E. Reid • \\ W. K. A. Karunarathne $\cdot$ D. M. Spence
}

Received: 20 June 2007 / Accepted: 7 September 2007 / Published online: 27 October 2007

(C) Springer-Verlag 2007

\begin{abstract}
Aims/hypothesis Proinsulin C-peptide has been implicated in reducing complications associated with diabetes and also in improving blood flow. We hypothesised that incubation of erythrocytes with C-peptide would improve the ability of these cells to release ATP, a stimulus for nitric oxide production.

Methods Erythrocytes obtained from rabbits $(n=11)$ and both healthy and type 2 diabetic humans $(n=7)$ were incubated with C-peptide in the absence and presence of $\mathrm{Fe}^{2+}$ and $\mathrm{Cr}^{3+}$, and the resulting ATP release was measured via chemiluminescence. This release was also measured in the presence and absence of phloretin, an inhibitor of GLUT1, and also of mannose, a glycolysis inhibitor. To determine glucose transport, ${ }^{14} \mathrm{C}$-labelled glucose was added to erythrocytes in the presence and absence of the C-peptide-metal complex and the aforementioned inhibitors.

Results The release of ATP from the erythrocytes of patients with diabetes increased from $64 \pm 13$ to $260 \pm$ $39 \mathrm{nmol} / 1$ upon incubation of the cells in C-peptide. The C-peptide activity was dependent upon binding to $\mathrm{Fe}^{2+}$,
\end{abstract}

J. A. Meyer · W. K. A. Karunarathne $\cdot$ D. M. Spence $(\bowtie)$

Department of Chemistry, Wayne State University,

5101 Cass Avenue,

Detroit, MI 48202, USA

e-mail: dspence@chemistry.msu.edu

J. M. Froelich

Department of Chemistry, Michigan State University,

East Lansing, MI, USA

G. E. Reid

Department of Biochemistry and Molecular Biology,

Michigan State University,

East Lansing, MI, USA

G. E. Reid

Department of Chemistry, Michigan State University,

East Lansing, MI, USA which was extended upon binding to $\mathrm{Cr}^{3+}$. The increase in ATP release from the erythrocytes is due to metal-activated C-peptide stimulation of glucose transfer into the erythrocytes via the GLUT1 transporter. In the presence of Cpeptide complexed to $\mathrm{Cr}^{3+}$, the amount of glucose transferred into the erythrocyte increased by $31 \%$.

Conclusions/interpretation When complexed to $\mathrm{Fe}^{2+}$ or $\mathrm{Cr}^{3+}$, C-peptide has the ability to promote ATP release from erythrocytes. This release is due to an increase in glucose transport through GLUT1.

Keywords Diabetes · C-peptide - Glucose transport · GLUT1 Chromium $\cdot$ Erythrocytes

Abbreviations
eNOS

\section{Introduction}

Diabetes is often typified by a lack of insulin production or resistance to the available insulin. The role of the insulin hormone is to facilitate glucose transport across cell membranes where it is then consumed or stored by the cell. Improper clearance of the glucose leads to hyperglycaemia and many associated complications including retinopathy, neuropathy, renal failure and cardiovascular disease.

Proinsulin C-peptide is created in the pancreas as a part of insulin production. For many years, this 31 amino acid peptide was thought to have minimal biological activity [1]. In the 1990s, researchers reported that C-peptide was able to ameliorate complications associated with diabetes in rat 
models, including vascular and neural dysfunction, glucose utilisation and renal function [2-4]. Other reports followed, demonstrating the ability of C-peptide to improve blood flow in the microvasculature [5] and skin [6] as well as improving the deformability of erythrocytes (ERYs) [7]. Cpeptide has also been reported to increase endothelial nitric oxide synthase (eNOS) activity [8].

The work involving C-peptide with ERY and eNOS activation is significant in light of Sprague's demonstration that ERYs are able to release ATP in response to stimuli including hypoxia, deformation and other agonists [9-11]. Importantly, ATP is a recognised stimulus of endotheliumderived nitric oxide (NO), a potent vasodilator. Sprague has demonstrated that this ERY-derived ATP is a determinant in vascular resistance in the isolated rabbit lung [12].

Collectively, reports demonstrating the ability of Cpeptide to increase both blood flow in the microvasculature and glucose transport in certain cell types, as well as those showing that ATP can be released from ERY in response to certain stimuli, suggest a potential novel role for C-peptide in vivo. We hypothesise that C-peptide has the ability to mediate the production of endothelium- or platelet-derived NO through an increase in the concentration of ATP released from ERY that have been subjected to incubation with physiological levels of C-peptide. Subsequent studies were performed to determine whether the increase in ATP release was due to activation of the major glucose transporter found in the ERY, GLUT1. An increase in GLUT1 activity would enhance glycolysis, the primary route by which ERYs produce ATP, thus activating a reported cyclic AMP-dependent pathway, by which ATP is released from the ERY [13].

Here, we demonstrate that ERYs are indeed able to release increased concentrations of ATP for a period of about $24 \mathrm{~h}$ when incubated with $\mathrm{C}$-peptide bound to $\mathrm{Fe}^{2+}$, whereas binding of C-peptide to $\mathrm{Cr}^{3+}$ results in sustained ATP release over a period of 3 to 5 days. A thorough examination indicates that the ATP release is related to an increase in glucose transport across the ERY membrane. Thus, C-peptide, when complexed to a metal, has properties similar to insulin, thus facilitating glucose transport across ERYs. Insulin does not perform this function directly on the major cellular component of the bloodstream (the ERY), thereby rendering the activity of metal-activated C-peptide crucial to proper blood glucose maintenance.

\section{Methods}

Preparation of ERYs Rabbits (male New Zealand whites, $2.0-2.5 \mathrm{~kg})$ were anaesthetised with ketamine $(8 \mathrm{ml} / \mathrm{kg}$, intramuscular) and xylazine $(1 \mathrm{mg} / \mathrm{kg}$, intramuscular) followed by pentobarbital sodium $(15 \mathrm{mg} / \mathrm{kg}$ i.v. $)$. A cannula was placed in the trachea and the animals were ventilated with room air. A catheter was placed into a carotid artery for administration of heparin and for phlebotomy. After heparin (500 U, i.v.), the animals were bled to death. Human blood was obtained by venipuncture without the use of a tourniquet (antecubital fossa) and collected into a heparinised syringe after informed written consent was obtained. Blood was centrifuged for $10 \mathrm{~min}$ at $500 \times g$ and $4{ }^{\circ} \mathrm{C}$. The plasma and buffy coat were discarded. The ERYs were resuspended and washed three times in a physiological salt solution (PSS) (in mmol/l: $4.7 \mathrm{KCl}$, 2.0 $\mathrm{CaCl}_{2}, 140.5 \mathrm{NaCl}, 12 \mathrm{MgSO}_{4}, 21.0$ tris[hydroxymethyl]aminomethane, 11.1 dextrose with $5 \% \mathrm{w} / v$ bovine serum albumin [final $\mathrm{pH}$ 7.4]). Cells were prepared on the day of use and experiments were finished within $8 \mathrm{~h}$ of removal from the animal or human participants. All procedures were approved by the Animal Investigation Committee or the Human Investigation Committee at Wayne State University.

Measurement of ATP Human C-peptide (American Peptide, Sunnyvale, CA, USA), $0.25 \mathrm{mg}$ (molecular mass 3,020), was dissolved in $100 \mathrm{ml}$ purified water $(18.2 \mathrm{M} \Omega)$ to yield a concentration of $83 \mu \mathrm{mol} / \mathrm{l}$. Next, an appropriate volume of this C-peptide solution was added to $10 \mathrm{ml}$ of a $7 \% \mathrm{v} / \mathrm{v}$ solution of ERYs to create a solution containing the Cpeptide at concentrations in the 1 to $10 \mathrm{nmol} / 1$ range. Detection of ATP release from the ERYs was performed using the luciferase assay and chemiluminescence measurement by a photomultiplier tube. The resultant current from the photomultiplier tube, which is proportional to the ATPinduced chemiluminescence, was measured as a potential by a data acquisition board controlled by a program written with LabView (National Instruments, Austin, TX, USA).

To ensure that cell lysis was not occurring during the assay, a solution of $0.01 \mathrm{~mol} / \mathrm{l}$ glibenclamide was prepared by adding $49 \mathrm{mg}$ of glibenclamide (Sigma-Aldrich, St. Louis, MO, USA) to $2 \mathrm{ml}$ of a $0.1 \mathrm{~mol} / 1$ solution of sodium hydroxide. To this, $7.94 \mathrm{ml}$ of a dextrose solution $(1 \mathrm{~g}$ dextrose $/ 20 \mathrm{ml}$ purified water) was added. The mixture was heated carefully to $52^{\circ} \mathrm{C}$ until all of the glibenclamide was dissolved. Once the solute was completely dissolved, $1 \mathrm{ml}$ of this solution was added to $9 \mathrm{ml} \mathrm{PSS}$, resulting in a solution with a concentration of $1 \mathrm{mmol} / \mathrm{l}$. From this diluted solution, $2.5 \mathrm{ml}$ were added to $2.5 \mathrm{ml}$ of $7 \%$ haematocrit $v / v$ ERY solution, resulting in a $3.5 \% v / v$ haematocrit solution of ERYs. This solution was allowed to incubate for $15 \mathrm{~min}$. As a comparison, $2.5 \mathrm{ml}$ of wash buffer without glibenclamide was added to $2.5 \mathrm{ml}$ of $7 \%$ haematocrit ERYs. After $15 \mathrm{~min}$, the ERY solutions were measured using the same methods as described above.

The solutions of $\mathrm{Cr}^{3+}$ and $\mathrm{Fe}^{2+}$ (derived from chromic chloride hexahydrate and ferrous ammonium sulphate 
hexahydrate, respectively) were prepared in purified water. The metal solutions were then added in equimolar amounts to the C-peptide solution (also in purified water) through a series of dilutions. Before adding to the ERYs, the metalC-peptide mixture was diluted in PSS to avoid any cell lysis that may occur upon direct contact of ERYs with a nonbuffered aqueous solution.

To determine the ability to inhibit glycolysis using mannose, $500 \mu \mathrm{l}$ of a $5.5 \mathrm{mmol} / \mathrm{l}$ solution of D-mannose that had been prepared in the PSS was added to the 7\% haematocrit ERYs solutions with and without the $1 \mathrm{nmol} / 1$ C-peptide. The resultant ATP release was measured after $6 \mathrm{~h}$ using the chemiluminescence assay described above. For the GLUT1 inhibition studies, the GLUT1 inhibitor phloretin was prepared by dissolving $0.100 \mathrm{~g}$ phloretin (Sigma-Aldrich) in an appropriate amount of dimethyl sulfoxide, followed by dilution to $50.0 \mathrm{ml}$ in phosphatebuffered saline yielding a final concentration of $0.5 \mathrm{mmol} / \mathrm{l}$. Next, $1.5 \mathrm{ml}$ of the $0.5 \mathrm{mmol} / \mathrm{l}$ phloretin solution was added to PSS containing C-peptide; after the addition of $500 \mu \mathrm{l}$ of ERYs ( $70 \%$ haematocrit) to the phloretin/peptide mixture, the solution was diluted to a final volume of $5 \mathrm{ml}$, resulting in a solution containing a 7\% haematocrit of ERYs in the presence of $10 \mathrm{nmol} / \mathrm{l} \mathrm{C}$-peptide and $\mathrm{Cr}^{3+}$. This solution was allowed to incubate for a period of $6 \mathrm{~h}$, followed by measurement of the ATP release from the ERYs using the luciferase assay for ATP.

Mass spectrometry analysis All experiments were performed using a Thermo model LTQ linear ion trap mass spectrometer (Thermo, San Jose, CA, USA). Samples were prepared by dissolving synthetic C-peptide in purified water at a concentration of $8.3 \mu \mathrm{mol} / \mathrm{l}$. For metal binding studies, $3.4 \mu \mathrm{l}$ of a $1 \mathrm{mmol} / 1$ solution of ferrous ammonium sulfate, ferric chloride or chromic chloride prepared in purified water was individually added to a C-peptide solution (final concentration of C-peptide of $8.3 \mu \mathrm{mol} / 1$ ) then introduced to the mass spectrometer at a flow rate of $0.5 \mu \mathrm{l} / \mathrm{min}$ by nanoelectrospray ionisation. The spray voltage was maintained at $2.0 \mathrm{kV}$. The heated capillary temperature was $250^{\circ} \mathrm{C}$. ${ }^{14} \mathrm{C}$-labelled glucose studies Experiments were performed
using ERYs that had been washed in a low glucose
concentration ( $0.55 \mathrm{mmol} / \mathrm{l}) \mathrm{PSS}$. The solution preparation
for C-peptide and all inhibitors remained the same as for
previous studies. Additionally, $1.554 \mathrm{~Bq}{ }^{14} \mathrm{C}$-labelled
glucose was added to the PSS. This created a ratio of
${ }^{14} \mathrm{C}-$ labelled glucose: non-radiolabelled glucose of $1: 10$.
ERYs were added creating a $7 \%$ haematocrit solution and
allowed to incubate for a period of $4 \mathrm{~h}$. After centrifugation
(at $500 \times g$ ), the ERYs were combined with a scintillation
cocktail and the radioactivity was measured using a
scintillation counter over a period of 3 min for each sample.

\section{Results}

C-peptide-induced release of ATP The ATP released by ERYs was measured using an established chemiluminescence assay $[14,15]$. Another aliquot from the same ERY sample was incubated in $1 \mathrm{nmol} / \mathrm{l} \mathrm{C}$-peptide and the resultant ATP release from the ERYs was measured every $2 \mathrm{~h}$ for a period up to $8 \mathrm{~h}$. Figure 1, which shows the normalised values of ATP released from the ERYs of 11 rabbits in the presence and absence of $\mathrm{C}$-peptide, indicates that the addition of C-peptide resulted in an increased release of ATP from the ERYs. Importantly, it was later verified through mass spectrometric analysis that the C-peptide used to obtain the data shown in Fig. 1 was bound to trace levels of $\mathrm{Fe}^{2+}$, an impurity in the commercially available product. The increase in ERY-derived ATP observed over the $8 \mathrm{~h}$ time period was almost three times greater than that of the ERYs incubated with a control (buffer without C-peptide). The increase in measured extracellular ATP release was not due to cell lysis, a conclusion formed from the inhibition of ATP release when the ERYs were incubated in glibenclamide. Glibenclamide is classically recognised as a chloride channel inhibitor that is also known to block the release of ATP via its ability to inhibit the cystic fibrosis transmembrane regulator protein [11].

Restoration of ATP release from the ERYs of patients with diabetes Recently, it has been reported that the ATP released from ERYs obtained from the whole blood of patients with type 2 diabetes mellitus is approximately $50 \%$ of that released from the ERYs of healthy control patients [14]. It was concluded that the ERYs of patients with

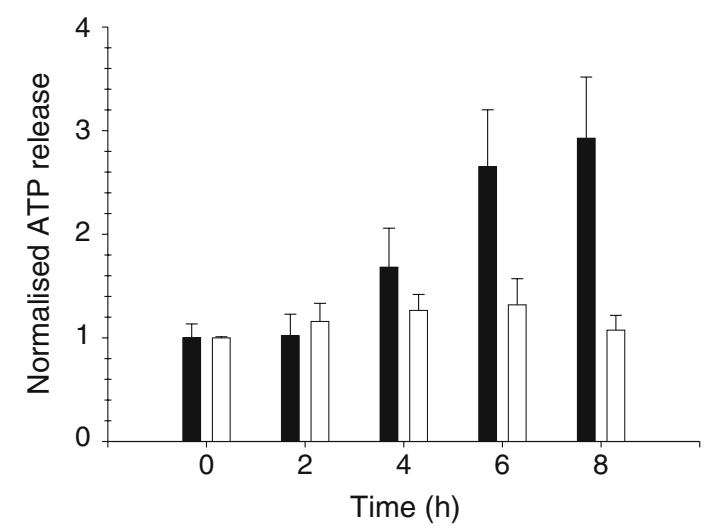

Fig. 1 Determination of ATP release from rabbit ERYs. The data shown are normalised values from the ERYs of 11 rabbits incubated in the presence and absence of $1 \mathrm{nmol} / \mathrm{l} \mathrm{C}$-peptide. ATP release (determined by a chemiluminescence assay) from cells incubated in C-peptide (filled bars) increased markedly after $4 \mathrm{~h}(p<0.005)$ and approximately 2.9-fold over a period of $8 \mathrm{~h}$ compared with ERYs incubated with no C-peptide (open bars). Although no metal was added, the C-peptide was bound to $\mathrm{Fe}^{2+}$ as verified by mass spectrometry. The metal was present as an impurity upon dissolution in the solvent (water). Error bars are $\pm \mathrm{SEM}$ 
diabetes may have released less ATP due to oxidative stress within the ERYs leading to a less deformable cell. A decrease in ERY deformability is a recognised trait of the ERYs obtained from patients with diabetes [16, 17]. Moreover, it has recently been reported that a decreased release of ATP from diabetic ERYs may be due to an inactivation of the $G_{i}$ protein subunit [13]. Due to the ability of C-peptide to increase ATP release from the ERYs of healthy rabbits, it was anticipated that C-peptide may be able to increase the ATP release from the ERYs of patients with type 2 diabetes. The data in Fig. 2 show that C-peptide not only has the ability to increase the ATP released (64 \pm $13 \mathrm{nmol} / \mathrm{l} \mathrm{ATP}$ at $0 \mathrm{~h}$ ) from the ERYs of patients with type 2 diabetes, but is also able to restore ATP levels (260土 $39 \mathrm{nmol} / 1$ at $6 \mathrm{~h}, n=7$ ) to a value that is statistically equivalent to that of healthy control patients [14]. Figure 2 also features data resulting from the analysis of ERYs obtained from healthy control patients. The ATP release from these participants $(260 \pm 60 \mathrm{nmol} / \mathrm{l}, n=7)$ in the presence of the peptide at $0 \mathrm{~h}$ was almost identical to that of the ERYs from the patients with type 2 diabetes after incubation with the peptide. Interestingly, the ATP release from the ERYs obtained from healthy control patients also increased $(480 \pm 109 \mathrm{nmol} / \mathrm{l}, n=7)$ after $6 \mathrm{~h}$ of incubation with C-peptide.

Mass spectrometry analysis of peptide-metal interactions Interestingly, the C-peptide exhibited significantly reduced activity, with respect to its ability to increase the concentrations of ERY-derived ATP, at 24 to $36 \mathrm{~h}$ after its preparation in water. Analysis of the C-peptide by electrospray ionisation mass spectrometry indicated that the peptide had not undergone any significant modification or degradation during this time, even after remaining in solution for periods $>30$ days. In addition, there have been no reports indicating secondary structures of C-peptide. Figure 3a shows the mass spectrum obtained following analysis of an $8.3 \mu \mathrm{mol} / 1$ solution of C-peptide freshly prepared in water. A high resolution scan of the triply charged region of the spectrum from Fig. 3a revealed that the peptide had formed adducts with various ions including sodium and potassium (Fig. 3b). Interestingly, this mass spectrum also showed that the C-peptide had formed an adduct with $\mathrm{Fe}^{2+}$. The deliberate addition of $\mathrm{Fe}^{2+}$ to the fresh C-peptide solution at a molar ratio of 2:1 resulted in the formation of this adduct as an abundant species (Fig. 3c). A high resolution scan of the region of the mass spectrum containing the dominant triply charged $\left[\mathrm{M}+\mathrm{H}^{+}+\mathrm{Fe}^{2+}\right]^{3+}$ adduct is shown in Fig. 3d. In order to extend the activity of the C-peptide, it was thought that the addition of a metal ion that has a slower exchange rate with ligands in solution could be employed to achieve successful maintenance of biological activity. Therefore, $\mathrm{Cr}^{3+}$ was added to a freshly prepared $8.3 \mu \mathrm{mol} / \mathrm{l}$ solution of $\mathrm{C}$-peptide at a molar ratio of

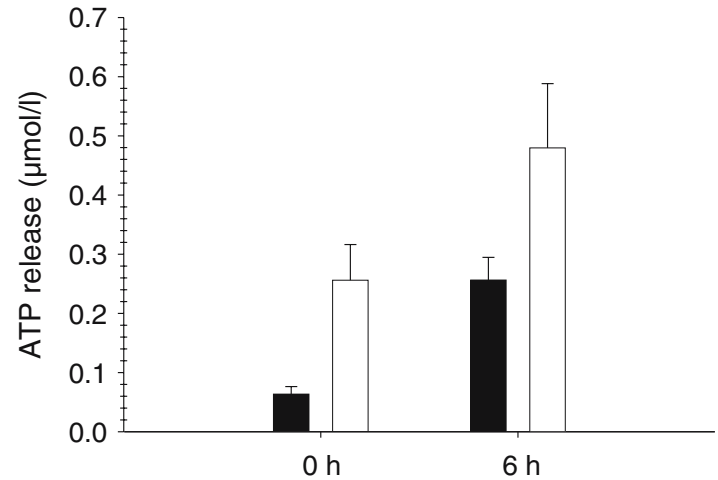

Fig. 2 ERYs obtained from human patients with diabetes (filled bars) released $64 \pm 13 \mathrm{nmol} / 1 \mathrm{ATP}$ at $0 \mathrm{~h}$. After incubation with Cpeptide for $6 \mathrm{~h}$, the ATP release increased $(p<0.005)$ to $260 \pm$ $39 \mathrm{nmol} / \mathrm{l}$. The release of ATP from ERYs obtained from human control patients (open bars) was $260 \pm 60 \mathrm{nmol} / \mathrm{l}$ at $0 \mathrm{~h}$ and $480 \pm$ $109 \mathrm{nmol} / 1$ at $6 \mathrm{~h}(p<0.005)$. The $\mathrm{C}$-peptide-metal adduct increased the ATP release from the ERYs obtained from patients with type 2 diabetes to a value that is statistically identical to that from ERYs of the healthy control participants. Error bars are \pm SEM $(n=7)$

2:1 and analysed by electrospray ionisation mass spectrometry (Fig. 3e). It can be seen in Fig. 3e and $\mathrm{f}$ that the dominant adduct produced by this addition corresponded to the monomeric $\left[\mathrm{M}+\mathrm{H}^{+}+\mathrm{Cr}^{3+}\right]^{4+}$ ion, with a non-covalent dimeric C-peptide adduct corresponding to $\left[2 \mathrm{M}+\mathrm{Cr}^{3+} \cdot 6 \mathrm{H}_{2} \mathrm{O}+2 \mathrm{H}^{+}\right]^{5+}$ also being observed, albeit at a relative abundance of only $35 \%$ of that of the $\left[\mathrm{M}+\mathrm{H}^{+}+\mathrm{Cr}^{3+}\right]^{4+}$ ion.

Extension of C-peptide activity though binding to $\mathrm{Cr}^{3+}$ Based on the data shown in Fig. 3, which demonstrated the ability of the C-peptide to bind to $\mathrm{Fe}^{2+}$ and $\mathrm{Cr}^{3+}$, ERYs were incubated in C-peptide solutions containing $\mathrm{Fe}^{2+}$ or $\mathrm{Cr}^{3+}$ and their subsequent ability to release ATP was determined (Fig. 4). As a negative control, ERYs were incubated in Cpeptide that had been kept at $4^{\circ} \mathrm{C}$ for $>30$ days. As expected, this solution no longer had the ability to induce ATP release from the ERYs. C-peptide that had been purified using HPLC also demonstrated no activity in the presence of ERYs. Furthermore, ERYs incubated with the metal ions in the absence of C-peptide also failed to increase ATP release. In contrast, an increase in ATP release was observed after incubation of the ERYs for $6 \mathrm{~h}$ in a $1 \mathrm{nmol} / 1$ solution of the inactive C-peptide to which $1 \mathrm{nmol} / 1 \mathrm{Fe}^{2+}$ or $\mathrm{Cr}^{3+}$ had been added, clearly demonstrating that the activity of the C-peptide was restored upon metal binding.

Although the $\mathrm{Fe}^{2+}$-bound $\mathrm{C}$-peptide had the ability to increase the ATP derived from the ERYs, its activity decreased after about $24 \mathrm{~h}$. For example, the activity of the C-peptide solution $72 \mathrm{~h}$ after addition of $\mathrm{Fe}^{2+}$ generally showed only a very slight increase against that of ERYs incubated in the absence of C-peptide (Fig. 4). Deliberate oxidation of a fresh $\mathrm{Fe}^{2+}$-bound $\mathrm{C}$-peptide solution or the 

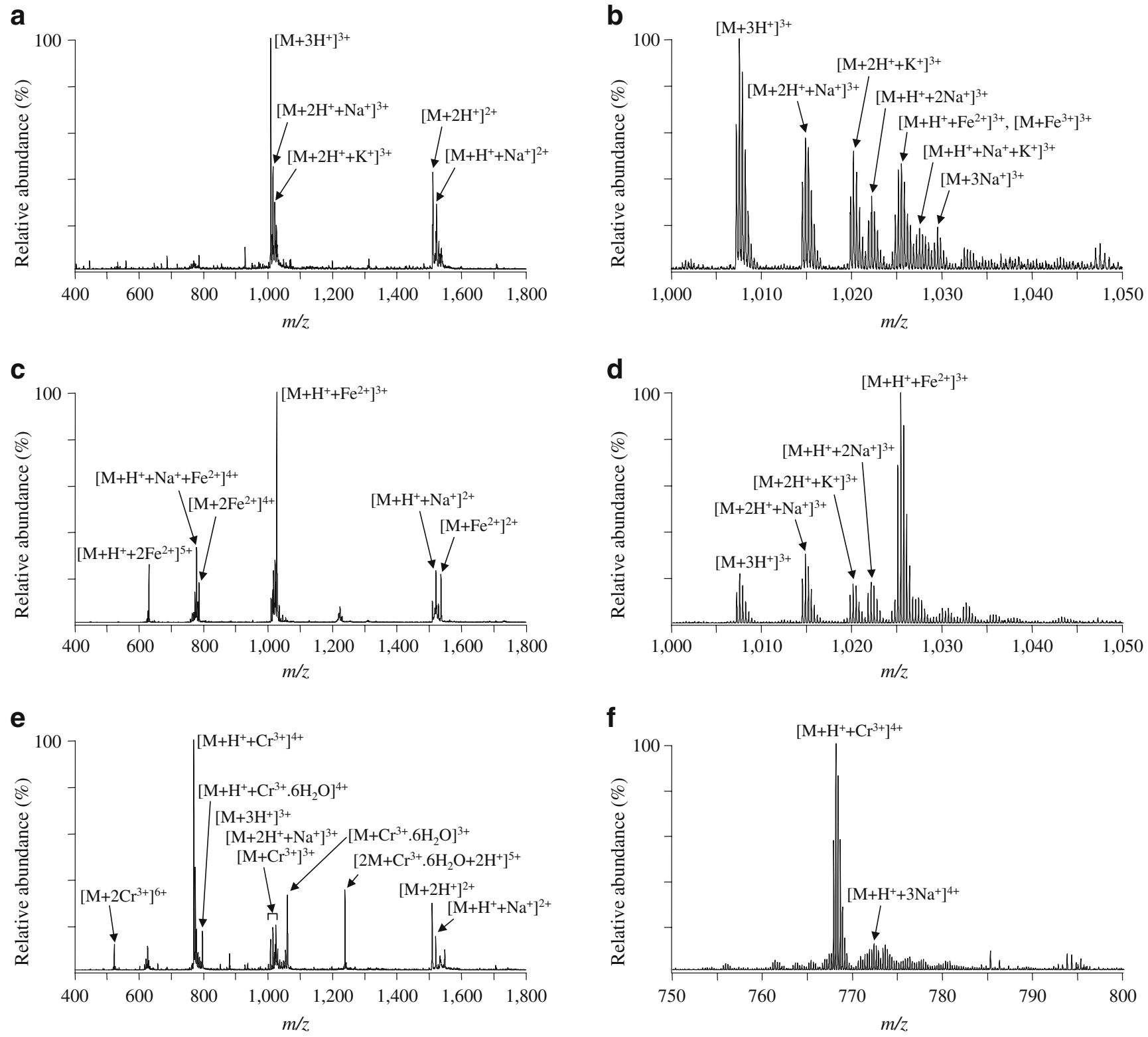

Fig. 3 Nanoelectrospray ionisation mass spectrometry analysis of Cpeptide and its metal adducts. a Mass spectrum of freshly prepared Cpeptide, b high-resolution mass spectrum of the $\left[\mathrm{M}+3 \mathrm{H}^{+}\right]^{3+}$ region from a, $\mathbf{c}$ mass spectrum of $\mathrm{C}$-peptide incubated with $\mathrm{Fe}^{2+}$, $\mathbf{d}$ highresolution mass spectrum of the $\left[\mathrm{M}+\mathrm{H}^{+}+\mathrm{Fe}^{2+}\right]^{3+}$ region from $\mathbf{c}, \mathbf{e}$ mass

direct addition of $\mathrm{Fe}^{3+}$ to a fresh C-peptide solution, followed by mass spectrometry analysis, revealed only minimal formation of an $\mathrm{Fe}^{3+}$ adduct, suggesting that oxidation of $\mathrm{Fe}^{2+}$ to $\mathrm{Fe}^{3+}$ was responsible for this loss of activity (data not shown). Moreover, ERYs incubated with a solution of C-peptide to which $\mathrm{Fe}^{3+}$ had been freshly added also failed to increase ATP release from these cells.

In contrast to that observed for the C-peptide in the presence of $\mathrm{Fe}^{2+}$, the increase in ERY-derived ATP release for the C-peptide solution at $72 \mathrm{~h}$ after addition of $\mathrm{Cr}^{3+}$ was essentially the same as that seen at the $6 \mathrm{~h}$ time period,

spectrum of C-peptide incubated with $\mathrm{Cr}^{3+}$, $\mathbf{f}$ high-resolution mass spectrum of the $\left[\mathrm{M}+\mathrm{H}^{+}+\mathrm{Cr}^{3+}\right]^{4+}$ region from e. Mass spectra were acquired using the 'enhanced' (a, c, e) and 'ultrazoom' (b, d, f) resonance ejection scan modes of the linear ion trap mass spectrometer

indicating that the activity of the C-peptide was extended to at least 3 days upon binding to $\mathrm{Cr}^{3+}$.

Enhanced glucose transport In separate reports, Sprague has suggested cellular pathways explaining the mechanism for the release of ATP from ERYs. [16] While there have been subtle differences, each mechanism reported involves activation of adenylyl cyclase and subsequent production of cyclic AMP from ATP. Glycolysis is the main, if not only route, by which ERYs produce ATP. Therefore, experiments were performed to determine whether the increased ATP release from the ERY 


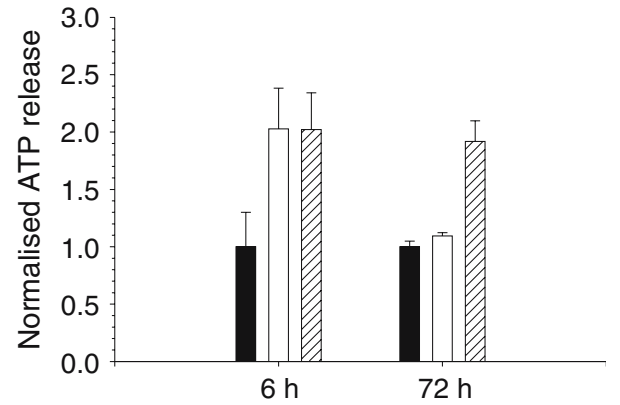

Fig. 4 Normalised ATP release from fresh ERYs after incubation with a C-peptide solution in contact with a metal after 6 and $72 \mathrm{~h}$. At $6 \mathrm{~h}$ the C-peptide solutions containing $\mathrm{Fe}^{2+}$ (open bars) and $\mathrm{Cr}^{3+}$ (hatched bars) had similarly increased $(p<0.005)$ ATP release. After $72 \mathrm{~h}$, the ATP release from ERYs incubated with the $\mathrm{Fe}^{2+}$ peptide solution decreased to a level similar to that from ERYs without any peptide (filled bars). The $\mathrm{Cr}^{3+}$ peptide solution maintained its level of activity. Error bars are \pm SEM $(n=4)$. It should be noted that, although very small, the difference in ATP release from ERYs incubated in the $72 \mathrm{~h}$ $\mathrm{Fe}^{2+} /$ peptide solution vs that from ERYs without any peptide was statistically significant $(p<0.01)$

in the presence of the C-peptide-metal complex was due to enhanced cyclic AMP production (via an increase in glycolytic ATP, a substrate for adenylyl cyclase). To test this hypothesis, ERYs were incubated in the presence and absence of phloretin, a GLUT1 inhibitor, and C-peptide activated with $\mathrm{Cr}^{3+}$. As shown in Fig. 5a, the $\mathrm{Cr}^{3+}$-activated C-peptide resulted in an increase in ATP release of $74 \%$. This increase was not obtained when the ERYs were incubated with phloretin prior to introduction of the $\mathrm{Cr}^{3+}$-activated C-peptide. These results suggest that ATP release from the ERYs was dependent upon the ability of the C-peptide to increase glycolysis within the ERY via increased cellular glucose transport through GLUT1. However, phloretin is a chloride ion channel inhibitor and, therefore, may also inhibit ATP release from the ERYs. Additionally, D-mannose inhibits ERY glycolysis probably through the glycolytic enzyme phosphoglucose isomerase. Upon addition of a mannose solution to ERYs and $1 \mathrm{nmol} / \mathrm{l} \mathrm{C}$-peptide, the ATP release was reduced to levels of ERYs alone, while the ERYs with metal-activated Cpeptide saw increased levels of ATP as shown in Fig. 5b.

To provide further evidence that the metal-activated Cpeptide facilitates glucose transport into the ERY, ${ }^{14} \mathrm{C}$-labelled glucose was included in the PSS at a 1:10 ratio with unlabelled glucose creating competition between the different glucose isotopes. As shown in Fig. 6, the amount of glucose entering the ERY increased by $31 \%$ when the ERY solution contained $\mathrm{Cr}^{3+}$-activated $\mathrm{C}$-peptide. While this increase in glucose transport was not as high as the ATP released from the ERYs, it should be noted that the ratio of radio-labelled glucose to unlabelled glucose was not stoichiometrically equivalent. In addition, ERYs incubated with the metal ions in the absence of C-peptide did not result in any increase in glucose transport across the ERY membrane or, as mentioned above, in ERY-derived ATP release.

\section{Discussion}

The results presented here show that C-peptide has the ability to increase the release of ATP from ERYs due to an activation of GLUT1. Importantly, the activity is only present when the C-peptide is bound to a metal such as $\mathrm{Fe}^{2+}$ or $\mathrm{Cr}^{3+}$. Recent reports have provided evidence suggesting a biological role for C-peptide and many of these positive aspects of Cpeptide have been debated by Wahren [18]. For example, it has been established that C-peptide increases renal function in patients with type 1 diabetes [19], endoneurial blood flow [20] and blood flow in the circulation [6, 21].

The improvement in blood flow reported by different groups applying C-peptide may be explained by the increase in ATP release from ERYs subjected to the C-peptide. ATP is a recognised stimulus of $\mathrm{NO}$ production in the endothelium and the ability of C-peptide to release increased levels of ATP from the ERYs is verified by our data in Fig. 1. It is
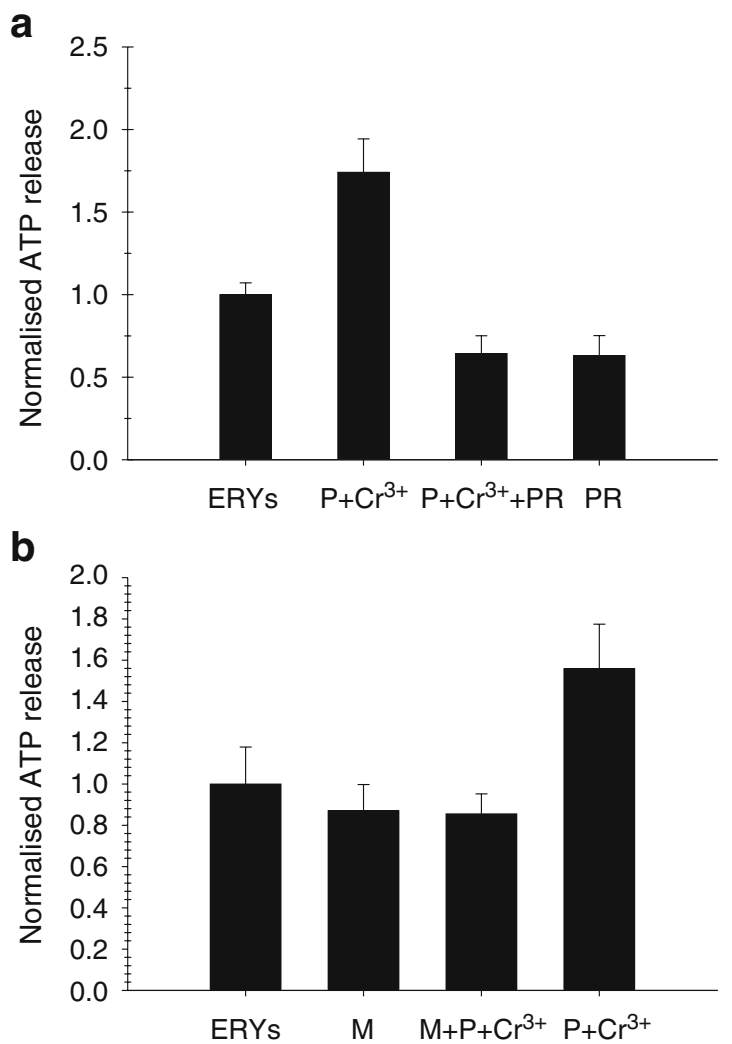

Fig. 5 a ERYs incubated with $10 \mathrm{nmol} / 1 \mathrm{Cr}^{3+}$-activated C-peptide $\left(\mathrm{P}+\mathrm{Cr}^{3+}\right)$ showed a significant $(p<0.005)$ increase in ATP release (approximately 74\%). However, when ERYs were incubated with the GLUT1 inhibitor phloretin (PR) prior to addition of $\mathrm{P}+\mathrm{Cr}^{3+}$, ATP release was only about $63 \%$ of the value for the ERYs alone. Error bars are \pm SEM $(n=8)$. b ATP release of ERYs that had been incubated with mannose $(\mathrm{M})$ and $\mathrm{P}+\mathrm{Cr}^{3+}$ showed a $57 \%$ decrease in ATP release against ERYs incubated with $\mathrm{P}+\mathrm{Cr}^{3+}$ alone, bringing ATP release to a level not significantly different from that in ERYs. However, in ERYs incubated with $\mathrm{P}+\mathrm{Cr}^{3+}$ the signal intensity was approximately $64 \%$ higher than in ERYs alone $(p<0.005)$ Error bars are $\pm \operatorname{SEM}(n=5)$ 


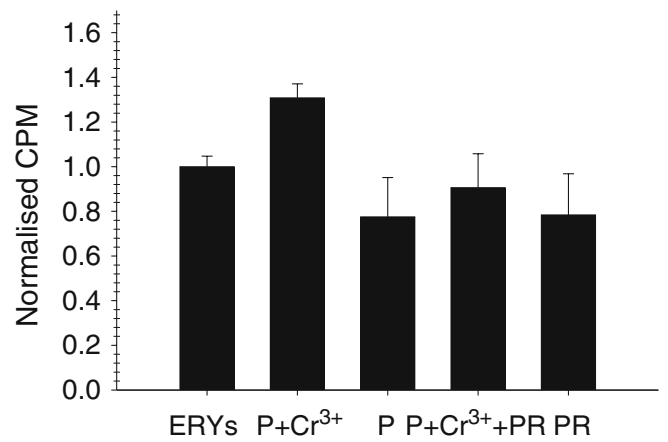

Fig. 6 ERYs incubated with $1.554 \mathrm{~Bq}{ }^{14} \mathrm{C}$-labelled glucose in a solution of PSS containing normal glucose. After $4 \mathrm{~h}$, the ERYs incubated with $10 \mathrm{nmol} / 1 \mathrm{Cr}^{3+}$-activated C-peptide $\left(\mathrm{P}+\mathrm{Cr}^{3+}\right)$ showed an approximately $31 \%$ increase in radioactive counts per min (cpm), while ERYs incubated with only C-peptide (P), $\mathrm{Cr}^{3+}$-activated $\mathrm{C}$ peptide plus the GLUT1 inhibitor phloretin (PR) or PR alone all showed no increase in CPM. Error bars are $\pm \operatorname{SEM}(n=4)$

important to note that in Fig. 1, the peptide had trace levels of metal bound to it in the form of $\mathrm{Fe}^{2+}$. The presence of this metal, which occurred as a trace level impurity in the commercially available product, was verified by the mass spectrometry experiments. As stated above, in the absence of metals such as $\mathrm{Fe}^{2+}$ or $\mathrm{Cr}^{3+}$, the C-peptide's activity (in terms of its ability to facilitate glucose transport and stimulate ATP release from the ERYs) was not present.

The data presented in Fig. 3 demonstrate that C-peptide has the ability to bind metals. In addition, the results shown in Fig. 4 suggest that when C-peptide binds to $\mathrm{Fe}^{2+}$, activity occurs, lasting for about $24 \mathrm{~h}$. However, when binding to $\mathrm{Cr}^{3+}$, the activity lasts for at least 3 days. These results are interesting in view of the fact that the exchange rate for $\mathrm{Fe}^{2+}$ binding to most ligands is generally faster than that for $\mathrm{Cr}^{3+}$ species binding to similar ligands. In other words, if the $\mathrm{Fe}^{2+}$ binds to the C-peptide, its activity lasts for a short period, but upon replacement of the $\mathrm{Fe}^{2+}$ (for example, with $\mathrm{Na}^{+}$or $\mathrm{K}^{+}$), the C-peptide has no activity.

In a separate report, Luzi et al. [22] has debated the negative concepts of $\mathrm{C}$-peptide. For example, despite efforts, a receptor for C-peptide has never been reported. However, it is highly probable that receptor-based experiments on ERYs have yet to be performed. It is also highly likely that, if a receptor for C-peptide does exist, the C-peptide would need to assume a proper structure for receptor binding. C-peptide has previously been shown to lack a stable secondary structure [23, 24]. One hypothesis to explain the results observed here is that coordination of $\mathrm{Cr}^{3+}$ to specific sites within the C-peptide molecule may result in the formation of a stable secondary structure that facilitates intracellular signal transduction via conformation-dependent interactions between the C-peptide-metal complex and a specific (yet to be identified) cell surface receptor. Alternatively, coordination of $\mathrm{Cr}^{3+}$ metal ions (or other metal ions) may facilitate the formation of a stable bioactive $\mathrm{C}$-peptide dimer. Further structural characterisation studies are currently underway to examine these hypotheses. The need for metal activation may also help explain the lack of successful clinical trials involving C-peptide.

Another negative concern with C-peptide is that the question still remains why people with type 2 diabetes have many of the well-known complications associated with diabetes yet have elevated concentrations of C-peptide. Recently, Carroll et al. [14] reported that the ATP released from the ERYs of patients with type 2 diabetes was approximately $50 \%$ of ATP released from healthy controls. It was concluded from this study that a decrease in glucose-6phosphate dehydrogenase activity, a common trait in the diabetic ERY, leads to a less deformable cell and a decrease in G-protein activation upon deformation. In the present study, the ATP release from ERYs obtained from a sample set of patients with type 2 diabetes was shown to revert to normal levels in the presence of metal-activated C-peptide (Fig. 2). Interestingly, in a separate report, Sprague has demonstrated that ATP release was decreased in the ERYs of patients with type 2 diabetes due to improper accumulation of cyclic AMP levels in the ERYs of these patients. Therefore, in such a scenario, C-peptide activation of glucose transport and subsequent ATP release from the ERY may not occur due to other complications within the diabetic ERY itself, such as glycation of key proteins in the ATP release pathway [13].

Future work should involve determination of the structure-function relationship between metal-activated Cpeptide and ERYs. Specifically, it is imperative to perform a quantitative determination of those metals actually bound to the C-peptide in vivo. For example, recent work has suggested that a polymorphism in the zinc transporter SLC30A8, which is expressed in beta cells where proinsulin is produced, has a direct correlation with type 2 diabetes [25]. The work presented here may be a platform to explain the implications of this zinc transporter problem, especially as unpublished results in our labs have indicated that $\mathrm{Zn}^{2+}$ also has the ability to stimulate the activity of C-peptide upon adduct formation.

Acknowledgements This study was supported by grants from the National Institutes of Health (DK 071888 and HL 073942).

Duality of interest The authors declare that there is no duality of interest associated with this manuscript.

\section{References}

1. Kunt T, Forst T, Pfutzner A, Beyer J, Wahren J (1999) The physiological impact of proinsulin C-peptide. Pathophysiology 5:257-262

2. Johansson BL, Kernell A, Sjoberg S, Wahren J (1993) Influence of combined C-peptide and insulin administration on renal 
function and metabolic control in diabetes type 1. J Clin Endocrinol Metab 77:976-981

3. Johansson BL, Sjoeberg S, Wahren J (1992) The influence of human C-peptide on renal function and glucose utilisation in type 1 (insulin-dependent) diabetic patients. Diabetologia 35:121-128

4. Ido Y, Vindigni A, Chang K et al (1997) Prevention of vascular and neural dysfunction in diabetic rats by C-peptide. Science 277:563-566

5. Forst T, Kunt T (2004) Effects of C-peptide on microvascular blood flow and blood hemorheology. Exp Diabesity Res 5:51-64

6. Forst T, Kunt T, Pohlmann T et al (1998) Biological activity of Cpeptide on the skin microcirculation in patients with insulindependent diabetes mellitus. J Clin Invest 101:2036-2041

7. Kunt T, Schneider S, Pfutzner A et al (1999) The effect of human proinsulin C-peptide on erythrocyte deformability in patients with type I diabetes mellitus. Diabetologia 42:465-471

8. Wallerath T, Kunt T, Forst $\mathrm{T}$ et al (2003) Stimulation of endothelial nitric oxide synthase by proinsulin C-peptide. Nitric Oxide 9:95-102

9. Sprague RS, Stephenson, Alan H et al (1995) Effect of 1-NAME on pressure-flow relationships in isolated rabbit lungs: role of red blood cells. Am J Physiol Heart Circ Physiol 269:H1941-H1948

10. Sprague RS, Ellsworth, Mary L et al (1996) ATP: the red blood cell link to NO and local control of the pulmonary circulation. Am J Physiol Heart Circ Physiol 271:H2717-H2722

11. Sprague RS, Ellsworth ML, Stephenson AH, Kleinhenz ME, Lonigro AJ (1998) Deformation-induced ATP release from red blood cells requires cystic fibrosis transmembrane conductance regulator activity. Am J Physiol 275:H1726-H1732

12. Sprague RS, Olearczyk JJ, Spence DM, Stephenson AH, Sprung RW, Lonigro AJ (2003) Extracellular ATP signaling in the rabbit lung: erythrocytes as determinants of vascular resistance. Am J Physiol 285:H693-H700

13. Sprague RS, Stephenson AH, Bowles EA, Stumpf MS, Lonigro AJ (2006) Reduced expression of $G_{i}$ in erythrocytes of humans with type 2 diabetes is associated with impairment of both cAMP generation and ATP release. Diabetes 55:3588-3593
14. Carroll JS, Subasinghe W, Raththagala M et al (2006) An altered erythrocyte pentose phosphate pathway affects the ability of red cells to release ATP, a nitric oxide stimulus. Mol Biosys 2:305-311

15. Sprung RJ, Sprague RS, Spence DM (2002) Determination of ATP release from erythrocytes using microbore tubing as a model of resistance vessels in vivo. Anal Chem 74:2274-2278

16. Simpson LO (1985) Intrinsic stiffening of red blood cells as the fundamental cause of diabetic nephropathy and microangiopathy: a new hypothesis. Nephron 39:344-351

17. Schwartz RS, Madsen JW, Rybicki AC, Nagel RL (1991) Oxidation of spectrin and deformability defects in diabetic erythrocytes. Diabetes 40:701-712

18. Wahren J, Ekberg K, Jornvall H (2007) C-peptide is a bioactive peptide. Diabetologia 50:503-509

19. Wahren J, Ekberg K, Samnegard B, Johansson BL (2001) Cpeptide: a new potential in the treatment of diabetic nephropathy. Curr Diab Rep 1:261-266

20. Stevens M, Zhang W, Li F, Sima A (2004) C-peptide corrects endoneurial blood flow but not oxidative stress in type $1 \mathrm{BB} /$ Wor rats. Am J Physiol Endocrinol Metab 287:E497-E505

21. Johansson BL, Linde B, Wahren J (1992) Effects of C-peptide on blood flow, capillary diffusion capacity and glucose utilization in the exercising forearm of type I (insulin-dependent) diabetic patients. Diabetologia 35:1151-1158

22. Luzi L, Zerbini G, Caumo A (2007) C-peptide: a redundant relative of insulin? Diabetologia 50:500-502

23. Henriksson M, Shafqat J, Liepinsh E et al (2000) Unordered structure of proinsulin C-peptide in aqueous solution and in the presence of lipid vesicles. Cell Mol Life Sci 57:337-342

24. Henriksson M, Nordling E, Melles E et al (2005) Separate functional features of proinsulin C-peptide. Cell Mol Life Sci 62:1772-1778

25. Sladek R, Rocheleau G, Rung J et al (2007) A genome-wide association study identifies novel risk loci for type 2 diabetes. Nature 445:881-885 